homepage: http://profesionalmudacendekia.com/index.php/jbmr

\title{
The Impact Of Leadership To Serve And Organizational Commitments To Employee Performance With Behavior Organizational Citizenship as Mediation Variable
}

Eni Istikhomah Sholikhah ${ }^{1}$,

Septi Kurnia Prastiwi ${ }^{2}$

1,2 Department of Sharia Business Management, Islamic Economic and Business Faculty IAIN Surakarta, Jl. Pandawa Pucangan Kartasura Sukoharjo, Indonesia

\section{ARTICLE INFO ABSTRACT}

ISSN: 0101-0720

Keywords:

Leadership to serve, Organizational Commitment, Employee Performance, Behavior Organizational Cifizenship
The aim of this study was to determine the influence of servant leadership and organizational commitment on employee performance with Organizational Citizenship Behavior (OCB) as a mediating variable (case study of the Center for Social Rehabilitation Prof. Dr. Soeharso Surakarta). The population in this study were employees of civil servants BBRSBD Prof. Dr. Soeharso Surakarta. With a sample used as many as 100 respondent. The technique of taking sample used is saturated sampling, where all populations are sampled entirely. Data collection techniques by distributing questionnaires. Data analysis techniques using Structural Equation Modeling (SEM) with the help of Partial Least Square (PLS) version 3.0.

The results of the study show that 1) there is no significant influence of leadership variables that serve organizational citizenship behavior; 2) There is a significant influence of organizational commitment variables on organizational citizenship behavior; 3) There is influence of leadership variables that serve employee performance; 4) There is no influence on organizational commitment variables on employee performance; 5) There is an influence of organizational citizenship behavior variables on employee performance.

\section{Pendahuluan}

Sebuah organisasi merupakan sebuah wadah yang dijadikan alat untuk mencapai tujuan bersama suatu organisasi, yang didalamnya terdapat kumpulan individu-individu dengan berbagai macam perilaku. Dilihat dari beberapa tahun terakhir ini terlihat banyak fungsi sumber daya manusia yang berperan melalui visi, strategi, struktur, proses dan sistem baru dalam sebuah organisasi untuk mencapai sebuah tujuan organisasi. Dalam mencapai tujuan suatu organisasi, sumber daya manusia mempunyai peran penting di samping sumber daya lain yang dimiliki oleh organisasi. Hal ini yang seharusnya disadari oleh organisasi, bahwa

Journal of Business and Management Review Vol. 1 No. 12020 Page 028-041

ISSN: 0101-0720

*Corresponding Author

Email address : septikurnia83@gmail.com 
keberhasilan untuk meningkatkan kualitas dan kuantitas sangat bergantung pada sumber daya manusia.

Tingkat efektivitas manajemen sumber daya manusia dipandang turut mempengaruhi kinerja suatu organisasi. Sumber daya manusia tidak hanya di definisikan apa yang sumber daya manusia lakukan, tetapi apa yang sumber daya manusia hasilkan. Sumber daya manusia dipandang semakin besar peranannya bagi kesuksesan suatu organisasi, maka banyak organisasi kini menyadari bahwa unsur "manusia" dalam organisasi dapat memberikan keunggulan bersaing (Rani, Mayasari, Bisnis, \& Batam, n.d.).

Suatu organisasi mempunyai tujuan salah satunya adalah meningkatkan kinerja karyawan. Meningkatkan kinerja karyawan akan menunjukkan peningkatan kinerja dalam organisasi. Kinerja karyawan didefinisikan sebagai suatu konsep usaha yang dilakukan untuk mencapai suatu tujuan organisasi dengan menggunakan potensi atau pengetahuan, serta keterampilan dan kemampuannya yang dimiliki (Altindag \& Kosedagi, 2015).

Dalam menilai suatu kualitas sumber daya manusia yang ada, dapat diukur dari kinerja suatu karyawan. Organisasi harus percaya bahwa untuk mencapai tingkatan yang baik, organisasi perlu mengusahakan kinerja karyawan yang sebaik mungkin dan setinggi-tingginya. Keberhasilan suatu organisasi dapat dilihat dari pencapaian kinerja oleh karyawan. Fakta tersebut yang menuntut karyawan untuk selalu menampilkan output yang optimal, dimana baik buruknya kinerja karyawan akan mempengaruhi pendapatan perusahaan secara menyeluruh (P. Robbins \& A. Judge, 2009).

Pemaparan diatas dapat membawa perubahan apabila dilakukan secara terus menerus dalam organisasi yaitu pada pekerja yang tetap bertahan dan pekerja yang memberontak. Hal ini yang menyebabkan banyak munculnya perilakuperilaku baik negatif maupun positif dalam organisasi, salah satunya adalah Organizational Citizhenship Behavior (OCB). Organizational Citizenship Behavior merupakan sebuah perilaku kebebasan yang bukan bagian dari persyaratan pekerjaan formal dari pekerja, tetapi pekerja berkontribusi pada lingkungan psikologis dan sosial di tempat kerja (Robbins \& Judge, 2016).

Seperti yang terjadi pada balai rehabilitasi di Kota Bengawan. Kota ini dikenal sebagai kota inklusi, salah satu lembaga difabel di Kota Surakarta adalah Balai Besar Rehabilitasi Sosial Bina Daksa (BBRSBD) Prof. Dr. Soeharso Surakarta. Organisasi tersebut berada dibawah naungan Kementrian Sosial Republik Indonesia. Organisasi ini selalu mengalami penurunan karyawan pada setiap tahunnya.

Seorang pemimpin sangat berperan untuk pengembangan seorang karyawan dan akan mampu memenuhi kebutuhan mendasar dari bawahannya. Seorang pemimpin sebagai penentu arah di dalam mengembangkan visi misi masa depan, seorang pemimpin biasanya melakukan hal-hal untuk masa yang jauh lebih maju, dengan berbagai strategi untuk menghasilkan perubahan yang diperlukan dalam meraih visi perusahaan (Griffin, 2004).

Kepemimpinan yang melayani didefinisikan sebagai pemimpin yang 
mengelola segala tantangan sebuah organisasi dengan mengesampingkan kepentingan pribadi kepada pemangku kepentingan organisasi atau masyarakat. Kepemimpinan yang melayani memandang kepemimpinan sebagai kesempatan untuk melayani baik individu, organisasi, dan masyarakat daripada sebagai wahana untuk mencapai kekuatan pribadi (Zou, Tian, \& Liu, 2015).

Pergantian kepemimpinan yang terjadi di BBRSBD Prof. Dr. Soeharso Surakarta, telah mengalami pergantian pemegang kekuasaan pada masa kepemimpinan yang berbeda-beda, berikut data yang kami peroleh. Peneliti mengambil data lima kepemimpinan terakhir yang terjadi pada Balai Besar Rehabilitasi Sosial Bina Daksa Prof. Dr. Soeharso Surakarta. Hal ini akan berpengaruh pada kinerja karyawan, karena jika dilogika kepemimpinan seorang kepala akan mempengaruhi kinerja bawahannya secara tidak langsung.

Berdasarkan fenomena dan research gap dalam pemaparan diatas, maka dalam penelitian ini bermaksud untuk mengetahui apakah terdapat pengaruh sikap perilaku kewargaan organisasi, kepemimpinan yang melayani dan komitmen organisasi yang dapat meningkatkan kinerja karyawan dengan optimal. Dengan demikian penulis mengadakan penelitian dengan tujuan mengetahui "Dampak Kepemimpinan Yang Melayani dan Komitmen Organisasi, Terhadap Kinerja Karyawan Dengan Organization Citizenship Behavior (OCB) Sebagai Variabel Mediasi (Studi Kasus Pada Balai Rehabilitasi Sosial Bina Daksa Prof. Dr. Soeharso Surakarta)"

\section{Metode}

Penelitian ini mengambil subyek karyawan dan karyawati Pegawai Negeri Sipil (PNS) Balai Besar Rehabilitasi Sosial Bina Daksa (BBRSBD) Prof. Dr. Soeharso Surakarta dengan jumlah 103 Karyawan.

Teknik pengambilan sampel yang digunakan dalam penelitian ini adalah sampling jenuh. Sampling jenuh adalah teknik penentuan sampel apabila semua anggota populasi digunakan semua sebagai sampel (Ferdinand, 2014). Sehingga dalam penelitian ini menggunakan sampel sebanyak 103 karyawan.

Teknik pengumpulan data dalam penelitian ini menggunakan kuesioner (angket). Kuesioner (angket) merupakan teknik pengumpulan data yang dilakukan dengan cara memberikan seperangkat pertanyaan secara tertulis kepada responden untuk dijawab (Sugiyono, 2014)

Kuesioner dalam penelitian ini tidak dipublikasikan secara online, dikarenakan pegawai Balai Rehabiltasi Sosial Bina Daksa (BBRSBD) Prof. Dr. Soeharso 50\% berumur lebih dari 50 tahun. Sehingga kuesioner dibagikan secara manual, dengan harapan responden lebih mudah dalam menerimanya.

\section{Teknik Analisis Data}

\section{SEM (Structural Equation Modeling)}


SEM merupakan model yang menjelaskan hubungan antara variabel laten. Variabel laten adalah variabel dependen dan independen dalam SEM, yang merupakan variabel yang tidak dapat bisa diukur secara langsung. Manfaat utama SEM adalah memiliki fleksibilitas yang tinggi bagi peneliti untuk menghubungkan antara teori dengan data (Haryono, 2017).

Dengan keterbatasan yang ada karena asumsi jumlah sampel yang besar, data harus terdistribusi secara normal, indikator harus dalam bentuk reflektif, model harus berdasar teori dan adanya indeterminasi, maka dalam penelitian ini menggunakan SEM berbasis variance atau component yaitu partial least square (PLS). Tidak jarang pula ditemukan hubungan diantara variabel yang sangat kompleks, tetapi dengan ukuran sampel yang kecil (Haryono, 2017).

\section{Ukuran Sampel dalam SEM-PLS}

Analisis PLS dimaksudkan untuk mengatasi masalah ukuran data yang kecil, adanya missing value, bentuk sebaran tidak normal dan skala pengukuran. Ukuran penelitian ini menggunakan ukuran sampel dengan pendekatan Cohen (1992), yang mempertimbangkan statistical power dan effect size ketika menentukan minimum ukuran sampel (Haryono, 2017).

Dalam model penelitian ini, jumlah anak panah (arah panah menuju konstruk) terbesar adalah 5. dengan mengharapkan signifikansi pada 0,05 (5\%) dan $\mathrm{R}^{2}$ minimum 0,25, maka ukuran sampel minimum yang harus kita punya adalah 70 sampel.

Tabel 3. Ukuran Sampel Model PLS-SEM Pendekatan Cohen

\begin{tabular}{|l|c|c|c|c|c|c|c|c|c|c|c|c|}
\hline \multirow{2}{*}{$\begin{array}{l}\text { Maximum Number } \\
\text { of Arrows Pointing }\end{array}$ at a Construct } & \multicolumn{9}{|c|}{ Significance Level } \\
\cline { 2 - 15 } & \multicolumn{4}{|c|}{ Minimum $\mathrm{R}^{2}$} & \multicolumn{4}{c|}{$5 \%$} & \multicolumn{4}{c|}{$10 \%$} \\
\cline { 2 - 15 } & 0,10 & 0,25 & 0,50 & 0,75 & 0,10 & 0,25 & 0,50 & 0,75 & 0,10 & 0,25 & 0,50 & 0,75 \\
\hline 2 & 158 & 75 & 47 & 38 & 110 & 52 & 33 & 26 & 88 & 41 & 26 & 21 \\
\hline 3 & 176 & 84 & 53 & 42 & 124 & 59 & 38 & 30 & 100 & 48 & 30 & 25 \\
\hline 4 & 191 & 91 & 58 & 46 & 137 & 65 & 42 & 33 & 111 & 53 & 34 & 27 \\
\hline 5 & 205 & 98 & 62 & 50 & 147 & 70 & 45 & 36 & 120 & 58 & 37 & 30 \\
\hline 6 & 217 & 103 & 66 & 53 & 157 & 75 & 48 & 39 & 128 & 62 & 40 & 32 \\
\hline 7 & 228 & 109 & 69 & 56 & 166 & 80 & 51 & 41 & 136 & 66 & 42 & 35 \\
\hline 8 & 238 & 114 & 73 & 59 & 174 & 84 & 54 & 44 & 143 & 69 & 45 & 37 \\
\hline 9 & 247 & 119 & 76 & 62 & 181 & 88 & 57 & 46 & 150 & 73 & 47 & 39 \\
\hline 10 & 256 & 123 & 79 & 64 & 189 & 91 & 59 & 48 & 156 & 76 & 49 & 41 \\
\hline
\end{tabular}

Sumber: (Haryono, 2017.

\section{Model Spesifikasi dengan PLS (Partial Least Square)}

\section{Evaluasi Outer Model (Model Pengukuran) dan Pengujian Validitas Konstruk}


Evaluasi outer model dilakukan dengan melihat hasil validitas indikator dan reabilitas konstruk yaitu convergent validity dan discriminant validity. Pengujian validitas konstruk terdapat pada outer model yaitu dengan melakukan evaluasi model pengukuran dengan melihat hasil convergent validity, discriminan validity dan composite reliability. 


\section{Convergent Validity}

Pada convergent validity, validitas indikator dapat dilihat dari nilai Loading Factor (LF). Nilai Loading Factor dikatakan valid apabila nilai Loading Factor $\geq 0,7$. Namun dalam pengembangan pengalaman empiris penelitian, nilai loading factor antara 0,5-0,6 masih dapat diterima. Sehingga dengan demikian jika nilai loading factor $\leq 0,4$ harus dikeluarkan.

Tabel 4. Tabel Loading Factor

\begin{tabular}{|c|c|c|c|}
\hline Indikator & Loading Factor & Convergen & Keterangan \\
\hline KK3 & 0,848 & $\geq 0,4$ & Valid \\
\hline KK4 & 0,865 & $>0,4$ & Valid \\
\hline KO1 & 0,760 & $>0,4$ & Valid \\
\hline KO2 & 0,808 & $\geq 0,4$ & Valid \\
\hline KO3 & 0,858 & $\geq 0,4$ & Valid \\
\hline KO4 & 0,688 & $>0,4$ & Valid \\
\hline OCB1 & 0,758 & $\geq 0,4$ & Valid \\
\hline OCB2 & 0,841 & $>0,4$ & Valid \\
\hline OCB3 & 0,778 & $>0,4$ & Valid \\
\hline KYM1 & 0,796 & $\geq 0,4$ & Valid \\
\hline KMY3 & 0,805 & $\geq 0,4$ & Valid \\
\hline
\end{tabular}

Berdasarkan tabel 4 dari hasil print out perintah calculate PLS Algoritm dapat diketahui bahwa nilai Loading Factor (LF) $\geq 0,4$ maka dapat dikatakan indikator tersebut sudah fit dalam model dan dapat mengukur konstruk yang dibentuknya.

\section{Discriminant Valid}

Discriminant Validity dapat diukur dari model reflektif yang dievaluasi melalui cross loading. Menurut (Haryono, 2017) ukuran cross loading adalah membandingkan korelasi indikator dengan konstruknya lebih tinggi dari korelasi dengan konstruk blok lainnya, memprediksi ukuran pada blok mereka dengan lebih baik daripada blok lainnya. Berikut hasil pengujian Discriminant Validity yang diperoleh:

Tabel 5. Discriminant Validity (Cross Loading)

\begin{tabular}{|c|c|c|c|c|}
\hline & $\begin{array}{c}\text { Kinerja } \\
\text { Karyawan }\end{array}$ & $\begin{array}{c}\text { Komitmen } \\
\text { Karyawan }\end{array}$ & OCB & $\begin{array}{c}\text { Servant Leadership } \\
\text { (Kepemimpinan } \\
\text { Yang Melayani) }\end{array}$ \\
\hline KK3 & $\mathbf{0 , 8 4 8}$ & 0,361 & 0,561 & 0,457 \\
\hline KK4 & $\mathbf{0 , 8 6 5}$ & 0,487 & 0,623 & 0,399 \\
\hline KO1 & 0,358 & $\mathbf{0 , 7 6 0}$ & 0,547 & 0,397 \\
\hline KO2 & 0,314 & $\mathbf{0 , 8 0 8}$ & 0,479 & 0,345 \\
\hline KO3 & 0,436 & $\mathbf{0 , 8 5 8}$ & 0,851 & 0,380 \\
\hline KO4 & 0,441 & $\mathbf{0 , 6 8 8}$ & 0,357 & 0,493 \\
\hline OCB1 & 0,485 & 0,491 & $\mathbf{0 , 7 5 8}$ & 0,430 \\
\hline OCB2 & 0,651 & 0,465 & $\mathbf{0 , 8 4 1}$ & 0,399 \\
\hline OCB3 & 0,500 & 0,567 & $\mathbf{0 , 7 7 8}$ & 0,274 \\
\hline
\end{tabular}




\begin{tabular}{|c|c|c|c|c|}
\hline & $\begin{array}{c}\text { Kinerja } \\
\text { Karyawan }\end{array}$ & $\begin{array}{c}\text { Komitmen } \\
\text { Karyawan }\end{array}$ & OCB & $\begin{array}{c}\text { Servant Leadership } \\
\text { (Kepemimpinan } \\
\text { Yang Melayani) }\end{array}$ \\
\hline SL1 & 0,390 & 0,403 & 0,732 & $\mathbf{0 , 7 9 6}$ \\
\hline SL3 & 0,408 & 0,418 & 0,369 & $\mathbf{0 , 8 0 5}$ \\
\hline
\end{tabular}

Sumber: Olah Data PLS, 2018

Dari Tabel 5. diketahui bahwa beberapa nilai loading factor untuk setiap indikator dari masing-masing variabel kepemimpinan yang melayani, organzation citizenship behavior, komitmen organisasi dan kinerja karyawan memiliki nilai loading factor yang lebih tinggi dibandingkan nilai loading factor variabel lainnya. Hal tersebut berarti bahwa setiap variabel laten memiliki discriminant validity yang baik dimana semua variabel laten memiliki pengukur yang berkorelasi tinggi dibanding dengan konstruk lainnya. Misalnya pada Variabel KK (Kinerja Karyawan), nilai loading factor nya lebih tinggi dibandingkan dengan nilai loading factor lainnya. Nilai loading factor terdapat pada kolom bercetak tebal.

\section{Pengujian Reabilitas Konstruk}

Kriteria validity dan reliabilitas juga dapat dilihat dari nilai reliabilitas suatu konstruk dan nilai Average Variance Extracted (AVE) untuk menunjukkan besarnya varian indikator yang dikandung oleh konstruknya.

\section{Mengevaluasi Reliability dan Average Variance Extracted (AVE)}

Evaluasi terhadap nilai reliabilitas konstruk diukur dengan nilai Composite Reliability. Konstruk dikatakan memiliki reliabilitas yang tinggi jika nilai Average Variance Extracted (AVE) $\geq 0,50$. Berikut adalah hasil pengukuran reliabilitas konstruk berdasarkan Convergent Validity.

Tabel 6. Convergent Validity

\begin{tabular}{|l|c|c|c|}
\hline & Cronbach Alpha & $\begin{array}{l}\text { Composite } \\
\text { Reliability }\end{array}$ & AVE \\
\hline KYM & 0,439 & 0,781 & 0,641 \\
\hline Kinerja Karyawan & 0,637 & 0,846 & 0,734 \\
\hline Komitmen & 0,784 & 0,861 & 0,610 \\
\hline OCB & 0,704 & 0,835 & 0,629 \\
\hline
\end{tabular}

Sumber: Data PLS, 2018

Berdasarkan tabel 4.16 dapat diketahui bahwa semua konstruk memenuhi kriteria reliabel yang cukup karena nilai composite reliability semua konstruk $\geq$ 0,6 yaitu kepemimpinan yang melayani, kinerja karyawan, komitmen organisasi dan organizational citizenship bejavior. Hasil pemeriksaan validity dapat diukur dengan melihat nilai AVE, dimana nilai $\mathrm{AVE} \geq 0,05$. Dari tabel diatas dapat diketahui nilai AVE $\geq 0,05$. 


\section{Evaluasi Model Struktural (Inner Model)}

Dalam evaluasi model struktural (inner model) terdapat tiga kriteria yang dapat dilakukan adalah dengan melihat signifikansi R-square, Q-square dan GoF dari model penelitian.

Gambar 2. Model Struktural

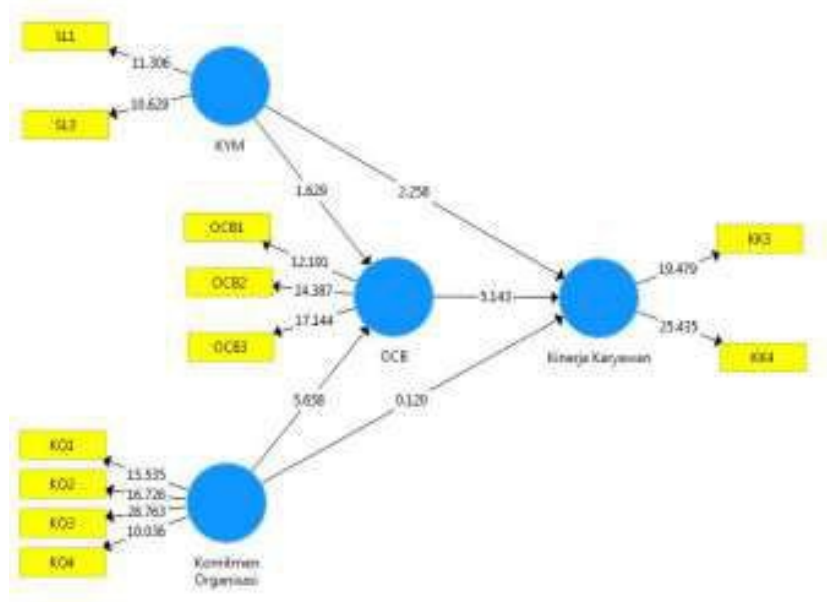

Pada gambar 7 merupakan gambar model struktural output koefisien jalur sebelum melakukan bootstrapping. Menilai model dengan parameter metode PLS dimulai dengan melihat R-square untuk setiap variabel dependen. Hasil nilai estimasi R-square adalah sebagai berikut:

Tabel 8. Nilai R-Square

\begin{tabular}{|l|c|c|}
\hline \multicolumn{1}{|c|}{ Variabel } & R-square & R Square \\
\hline Kinerja Karyawan & 0,519 & 0,504 \\
\hline Organizational Citizenship Behavior & 0,432 & 0,420 \\
\hline
\end{tabular}

Dari tabel 8 menunjukkan bahwa nilai R-square untuk variabel kinerja karyawan yaitu sebesar 0,519 atau $51,9 \%$ dan nilai R-square untuk variabel Organizational Citizenship Behaviour (OCB) sebesar 0,432 atau 43,2\%. sedangkan nilai $\mathrm{R}^{2}$ menunjukkan besarnya variability variabel yang dijelaskan oleh variabel eksogen (X). Sehingga dapat disimpulkan bahwa variabel kinerja karyawan dapat dipengaruhi oleh variabel eksogen sebesar 51,9\%, sedangkan untuk variabel Organizational Citizenship Behaviour (OCB) dapat dipengaruhi oleh variabel eksogen sebesar $43,2 \%$.

Pengujian inner model juga dapat dilakukan dengan melihat nilai Q2 (predictive relevance). Untuk menghitung Q2 dapat dihitung menggunakan rumus:

$$
\mathrm{Q} 2=1-\left(1-\mathrm{R} 1^{2}\right)\left(1-\mathrm{R} 2^{2}\right)
$$




$$
\begin{aligned}
& \mathrm{Q} 2=1-\left(1-0,519^{2}\right)\left(1-0,432^{2}\right) \\
& \mathrm{Q} 2=0,405715773 \\
& \mathrm{Q} 2=0,40
\end{aligned}
$$

Sehingga didapat nilai Q-Square sebesar 0,40. Pengujian Inner Model yang ke-3 juga dapat dilakukan dengan mencari nilai Goodness of Fit (GoF), untuk mencari nilai tersebut dapat dihitung secara manual dengan rumus berikut ini:

$$
\begin{aligned}
& \text { GoF }=\sqrt{\overline{A V E} \times \overline{R^{2}}} \\
& \text { GoF }=\sqrt{0,6535 \times 0,462} \\
& \text { GoF }=\sqrt{0,30} \\
& \text { GoF }=0,54
\end{aligned}
$$

Nilai GoF adalah 0,54 yang berarti nilai tersebut masuk dalam kategori besar. Interpretasi nilai GoF menurut (Tenenhaus 2014 dalam Sabil Husein, 2015) bahwa nilai GoF adalah 0,1 (GoF kecil), 0,25 (GoF sedang), 0,38 (GoF Besar). Sehingga dari perhitungan Inner Model $\left(\mathrm{R}^{2}, \mathrm{Q}^{2}\right.$ dan $\left.\mathrm{GoF}\right)$ terlihat bahwa model yang dibentuk adalah robust, sehingga pengujian hipotesis dapat dilakukan.

\section{Pengujian Hipotesa}

Pada tahap pengujian hipotesa, evaluasi model struktural dianalisis dengan melihat signifikansi hubungan antar konstruk yang ditujukan oleh nilai t-statistik dengan melihat output dari option Calculate PLS Bootstrapping. Indikator dapat dikatakan valid apabila memiliki nilai T-statistik $\geq 1,96$ (t-tabel) atau nilai $\mathrm{p}$-value $\leq$ 0,05. Nilai T-statistik dapat dilihat pada tabel path coefficient. Berikut adalah tabel path coefficient.

Tabel 9. Path Coefficient 
Path Coefficients

\begin{tabular}{|c|c|c|c|c|c|c|c|c|}
\hline \multirow[t]{2}{*}{ Mean, STDEV, } & -Values, $\mathrm{P}$-Va... & \multicolumn{2}{|c|}{ Confidence Intervals } & (1) Confidence Intervals Bias $\mathrm{C}$... & Samples & Copyt & oard: & Exc \\
\hline & \multicolumn{2}{|c|}{ Original Sample (0) } & Sample Mean (M) & Standard Deviation (STDEV) & \multicolumn{2}{|c|}{ T Statistics (|O/STDEV|) } & \multicolumn{2}{|c|}{$P$ Values } \\
\hline KYM $\rightarrow$ Kinerja... & & 0.223 & 0.234 & 0.099 & & 2.258 & 0.0 & 124 \\
\hline $\mathrm{KYM} \rightarrow \mathrm{OCB}$ & & 0.185 & 0.190 & 0.114 & & 1.629 & 0.1 & .04 \\
\hline Komitmen Org... & & 0,012 & 0.009 & 0.098 & & 0.120 & 0.9 & 305 \\
\hline Komitmen Org... & & 0.543 & 0.538 & 0.096 & & 5.658 & 0. & 000 \\
\hline$O C B$ - Kinerja... & & 0.581 & 0.570 & 0.113 & & 5.143 & 0.0 & 000 \\
\hline
\end{tabular}

Sumber: Data diolah PLS, 2018

Berdasarkan tabel 9 Path Coefficient maka dapat dilakukan pengujian hipotesis sebagai berikut:

Tabel 9 menunjukkan bahwa hubungan variable kepemimpinan yang melayani berpengaruh secara signifikan terhadap variabel kinerja karyawan. Hal ini dapat dibuktikan nilai T-statistic 2,258 $\geq 1,96$ dan pada nilai p-value dengan nilai $0,024 \leq 0,05$.

Variabel servant leadership berpengaruh tidak signifikan terhadap variabel organization citizenship behavior. Hal tersebut dapat dibuktikan pada hasil diatas dengan nilai T-statistic 1,629 $\leq 1,96$ dan pada nilai $p$-value dengan nilai $0,104 \geq$ 0,05. Sehingga dapat disimpulkan bahwa servant leadership berpengaruh tidak signifikan terhadap Organization Citizenship Behavior.

Pada tabel 4.18 menunjukkan bahwa variabel komitmen organisasi tidak berpengaruh secara signifikan terhadap variabel kinerja karyawan. Hal ini dapat dilihat pada kolom T-statistic dengan nilai $0,120 \leq 1,96$ dan pada nilai p-value dengan nilai $0,905 \geq 0,05$.

Dapat dilihat juga pada tabel 4.19 menunjukkan bahwa hubungan antara variabel komitmen organisasi berpengaruh secara signifikan terhadap variabel organization citizenship behavior dengan nilai T-statistic 5,143 $\geq 1,96$ dan memiliki nilai p-value dengan nilai $0,000 \leq 0,05$. Sehingga dapat disimpulkan bahwa komitmen organisasi memiliki hubungan positif dan berpengaruh signifikan terhadap organizational citizenship behavior, dengan artian hal tersebut sesuai dengan (H2) yang berarti $\mathrm{H} 2$ diterima.

Pada tabel 4.18 menunjukkan bahwa hubungan variabel Organization Citizenship Behavior $(O C B)$ berpengaruh secara signifikan terhadap variabel kinerja karyawan. Hal ini dapat dilihat pada kolom T-statistic dengan nilai 5,143 $\geq 1,96$ dan pada nilai p-value dengan nilai $0,000 \leq 0,05$.

\section{Pengaruh Mediasi Metode Sobel}

Metode sobel digunakan untuk menjawab pengujian hipotesis secara tidak langsung antara variabel independen terhadap variabel dependen.

Pengaruh Kepemimpinan Yang Melayani Terhadap Kinerja Karyawan Dengan Mediasi Organization Citizenship Behavior (OCB) 
Pengujian pengaruh tidak la ngsung variabel servant leadership terhadap kinerja karyawan dengan mediasi Organization Citizenship Behavior (OCB) dapat dilakukan dengan mengetahui hasil pengujian Organization Citizenship Behavior (OCB) terhadap kinerja karyawan. Pengujian pengaruh mediasi dilakukan dengan menggunakan rumus sobel. Hasil pengujian menunjukkan nilai koefisien jalur sebesar 0,181 dengan diketahui nilai $t$ sebesar 1,700 sehingga diketahui nilai tersebut $\leq 1,96$. Hasil ini berarti variabel servant leadership tidak berpengaruh signifikan terhadap Organizational Citizenship Behaviour (OCB).

Pengujian terhadap pengaruh mediasi antar variabel intermediasi dengan variabel dependent dapat dilakukan dengan pertimbangan rumus sobel. hasil tersebut diketahui sebagai berikut:

$$
\begin{array}{ll}
\text { P1 }=0,181 & \text { Se1 }=0,106 \\
\text { P2 }=0,705 & \text { Se2 }=0,090
\end{array}
$$

Besarnya koefisien tidak langsung variabel servant leadership terhadap kinerja karya wa merupakan perkalian dari pengaruh variabel servant leadership dengan Organization Citizenship Behavior (OCB) terhadap kinerja karyawan, sehingga diperoleh hasil sebagai berikut:

$$
\begin{aligned}
& \text { P12 }=\text { P1 . P2 } \\
& \text { P12 }=0,181(0,705) \\
& \text { P12 }=0,127605
\end{aligned}
$$

Besarnya standart error servant leadership terhadap kinerja karyawan merupakan perkalian dari pengaruh variabel servant leadership dengan Organization Citizenship Behavior (OCB) terhadap kinerja karyawan, sehingga diperoleh sebagai berikut:

$$
\begin{aligned}
& S a b=\sqrt{P 1^{2} \cdot S e 2^{2}+P 2^{2} \cdot S e 1^{2}+S e 1^{2} \cdot S e 2^{2}} \\
& S a b=\sqrt{0,181^{2} 0,090^{2}+0,705^{2} 0,106^{2}+0,106^{2} 0,090^{2}} \\
& S a b=\sqrt{0,032761(0,0081)+0,497025(0,011236)+0,011236(0,0081)} \\
& S a b=\sqrt{0,0002653+0,0055845+0,000091} \\
& S a b=\sqrt{0,0059385} \\
& S a b=0,0770616
\end{aligned}
$$

Dengan demikian nilai uji $\mathrm{t}$ diperoleh sebagai berikut:

$$
\begin{aligned}
t & =\frac{a b}{S a b} \\
t & =\frac{0,127605}{0,0770616} \\
t & =1,655883
\end{aligned}
$$

Diketahui nilai $\mathrm{t}$ sebesar $1,655883 \leq \mathrm{t}$ tabel yaitu 1.96 dengan tingkat signifikan 0,05. Maka dengan demikian model pengaruh tidak langsung dari 
variabel kepemimpinan yang melayani terhadap kinerja karyawan melalui Organization Citizenship Behavior (OCB) sebagai variable mediasi tidak berpengaruh secara signifikan.

\section{Pengaruh Komitmen Organisasi Terhadap Kinerja Karyawan Dengan Mediasi Organizational Citizenship Behavior (OCB)}

Pengujian pengaruh mediasi dilakukan dengan menggunakan rumus sobel. Hasil pengujian langsung menunjukkan nilai koefisien jalur sebesar $-0,015$ dengan nilai $t$ sebesar 0,150 nilai tersebut menunjukkan $\leq 1,96$. Hal ini berarti variabel komitmen organisasi memiliki hubungan negatif dan tidak signifikan terhadap kinerja karyawan.

Pengujian terhadap pengaruh mediasi antar variabel mediasi dengan variabel dependen dilakukan dengan perhitungan rumus sobel. Hasil dari kedua pengujian diringkas sebagai berikut:

$$
\begin{array}{ll}
\text { P3 }=0,571 & \text { Se3 }=0,097 \\
\text { P2 }=0,705 & \text { Se2 }=0,090
\end{array}
$$

Besarnya koefisien tidak langsung variabel komitmen organisasi terhadap kinerja karyawan merupakan perkalian dari pengaruh variabel komitmen organisasi dengan Organization Citizenship Behavior (OCB) terhadap kinerja

$$
\begin{aligned}
& \text { P32 }=\text { P3 . P2 } \\
& \text { P32 }=0,403
\end{aligned}
$$

Besarnya standart error komitmen organisasi terhadap kinerja karyawan merupakan perkalian dari pengaruh variabel komitmen organisasi dengan Organization Citizenship Behavior (OCB) terhadap kinerja karyawan, sehingga diperoleh sebagai berikut:

$$
\begin{aligned}
& S a b=\sqrt{P 3^{2} \cdot S e 2^{2}+P 2^{2} \cdot S e 3^{2}+S e 3^{2} \cdot S e 2^{2}} \\
& S a b=\sqrt{0,571^{2}\left(0,090^{2}\right)+\left(0,705^{2}\right) 0,097^{2}+0,097^{2}\left(0,090^{2}\right)} \\
& S a b=0,085986
\end{aligned}
$$

Dengan demikian nilai uji t diperoleh sebagai berikut:

$$
\begin{aligned}
t & =\frac{a b}{S a b} \\
t & =\frac{0,403}{0,085986} \\
t & =4,6868094
\end{aligned}
$$

Diketahui nilai $\mathrm{t}$ sebesar 4,6868094 $\geq$ dari $\mathrm{t}$ tabel yaitu 1.96 dengan tingkat signifikan 0,05. Dengan demikian model pengaruh tidak langsung dari variabel komitmen organisasi terhadap kinerja karyawan melalui variabel mediasi 
Organization Citizenship Behavior (OCB) berpengaruh signifikan.

\section{Conclusion}

Dari penelitian yang dilakukan, kepemimpinan yang melayani berpengaruh signifikan terhadap organizational citizenship behavior" belum terbukti kebenarannya. Yang berarti servant leadership tidak berpengaruh signifikan terhadap organizational citizenship behaviour.

Komitmen organisasi berpengaruh signifikan terhadap perilaku kewargaan organisasi” terbukti kebenarannya. Dengan demikian bahwa komitmen organisasi memiliki hubungan yang positif dan berpengaruh signifikan terhadap organizational citizenship behaviour.

Kepemimpinan yang melayani berpengaruh secara signifikan terhadap kinerja karyawan" telah terbukti kebenarannya. Sehingga disimpulkan bahwa servant leadership berpengaruh signifikan terhadap kinerja karyawan.

Komitmen organisasi berpengaruh signifikan terhadap kinerja karyawan belum terbukti kebenarannya. Nilai original sampel diketahui adalah negative yang berarti variabel komitmen organisasi tidak berpengaruh signifikan terhadap kinerja karyawan.

Hipotesis kelima menyatakan bahwa organizational citizenship behaviour berpengaruh signifikan terhadap kinerja karyawan. Dengan demikian organizational citizenship behaviour berpengaruh signifikan terhadap kinerja karyawan.

\section{References}

Altindag, E., \& Kosedagi, Y. (2015). The Relationship Between Emotional Intelligence of Managers, Innovative Corporate Culture and Employee Performance. Procedia - Social and Behavioral Sciences, 210, 270-282.

Ferdinand, A. (2014). Metode Penelitian Manajemen (5th ed.). Semarang: Seri Pustaka Kunci.

Ghozali Imam. (2014). Struktural Equation Modeling, Metode Alternatif Dengan Partial Least Squares (edisi 4). Semarang: Undip Press.

Griffin, R. W. (2004). Manajemen (7th ed.). Jakarta: Erlangga.

Harwiki, W. (2016). The Impact of Servant Leadership on Organization Culture, Organizational Commitment, Organizational Citizenship Behaviour (OCB) and Employee

Performance in Women Cooperatives. Procedia - Social and Behavioral Sciences, 219, 283-290.

Haryono, S. (2017). Metode SEM Untuk Penelitian Manajemen AMOS LISREL PLS.Jakarta: Luxsima Metro Media.

Manajemen, J., Krisnadwipayana, B., Saputra, W., \& Wibowo, I. (2017). Pengaruh Gaya Kepemimpinan Terhadap Kinerja, 5(2), 1-19. 
P. Robbins, S., \& A. Judge, T. (2009). Perilaku Organisasi. (D. Sunardi, Ed.) (12th ed.). Jakarta: Salemba Empat.

Rani, I. H., Mayasari, M., Bisnis, J. M., \& Batam, P. N. (n.d.). Pengaruh Penilaian Kinerja Terhadap Kinerja Karyawan Dengan Motivasi Sebagai Variabel Moderasi.

Robbins, S. P., \& Judge, T. A. (2015). Perilaku Organisasi (16th ed.). Jakarta: Salemba Empat.

Robbins, S. P., \& Judge, T. A. (2016). Perilaku Organisasi. Jakarta: Salemba Empat.

Sugiyono. (2014). Metode Penelitian Kuantitatif, Kualitatif dan R\&D. Bandung: Alfabeta.

Sugiyono. (2017). Metode Penelitian Kuantitatif, Kualitatif dan R\&D (25th ed.). Bandung: Alfabeta.

Zou, W. C., Tian, Q., \& Liu, J. (2015). Servant leadership, social exchange relationships, and follower's helping behavior: Positive reciprocity belief matters. International Journal of Hospitality Management, 51, 147-156. https://doi.org/10.1016/j.ijhm.2015.08.012 